\title{
Article \\ Natural Killer Cell Line NK-92-Mediated Damage of Medically Important Fungi
}

\author{
Stanislaw Schmidt ${ }^{1, *}$, Marie Luckowitsch ${ }^{1}$, Michael Hogardt ${ }^{2}$ and Thomas Lehrnbecher ${ }^{1}$ \\ 1 Division of Pediatric Hematology and Oncology, Hospital for Children and Adolescents, University Hospital \\ Frankfurt, Goethe University, 60590 Frankfurt am Main, Germany; Marie.Luckowitsch@kgu.de (M.L.); \\ Thomas.Lehrnbecher@kgu.de (T.L.) \\ 2 Institute for Medical Microbiology and Infection Control, University Hospital Frankfurt, Goethe University, \\ 60590 Frankfurt am Main, Germany; Michael.Hogardt@kgu.de \\ * Correspondence: Stanislaw.Schmidt@kgu.de; Tel.: +49-69-6301-83928
}

Citation: Schmidt, S.; Luckowitsch, M.; Hogardt, M.; Lehrnbecher, T. Natural Killer Cell Line NK-92-Mediated Damage of Medically Important Fungi. J. Fungi 2021, 7, 144. https://doi.org/ 10.3390/jof7020144

Academic Editor: David S. Perlin Received: 1 February 2021

Accepted: 11 February 2021

Published: 17 February 2021

Publisher's Note: MDPI stays neutral with regard to jurisdictional claims in published maps and institutional affiliations.

Copyright: (c) 2021 by the authors. Licensee MDPI, Basel, Switzerland. This article is an open access article distributed under the terms and conditions of the Creative Commons Attribution (CC BY) license (https:// creativecommons.org/licenses/by/ $4.0 /)$.

\begin{abstract}
Invasive fungal disease (IFD) in hematopoietic stem cell transplantation is associated with high morbidity and mortality. As the antifungal host response determines risk and outcome of IFD, there is growing interest in adoptive immunotherapy using T cells or natural killer (NK) cells. Although the NK-92 cell line has been tested as anticancer therapy in clinical trials, data on the antifungal activity of NK-92 cells are lacking. Here, we show that the NK-92 cell line exhibits considerable fungal damage on all medically important fungi tested, such as different species of Aspergillus, Candida, mucormycetes, and Fusarium. The extent of fungal damage differs across various species of mucormycetes and Fusarium, whereas it is comparable across different species of Aspergillus and Candida. Interferon (IFN)- $\gamma$ levels in the supernatant were lower when NK-92 cells are co-incubated with Aspergillus fumigatus, Candida albicans, or Rhizopus arrhizus compared to the levels when NK-92 cells are incubated alone. Different to primary human NK cells, no increase of perforin levels in the supernatant was observed when the fungi were added to NK-92 cells. Our in vitro data demonstrated that the NK-92 cell line could be a feasible tool for antifungal immunotherapy, but data of animal models are warranted prior to clinical trials.
\end{abstract}

Keywords: natural killer cell; NK-92; antifungal activity; Aspergillus; Candida; Fusarium; mucormycetes

\section{Introduction}

Pediatric and adult patients undergoing allogeneic hematopoietic stem cell transplantation (HSCT) are at an increased risk for invasive fungal disease (IFD), which is still associated with high morbidity and mortality [1,2]. The incidence of IFDs in allogeneic HSCT recipients is approximately $15 \%$ [3,4]. In addition, despite the availability of new and potent antifungal compounds, such as broad-spectrum triazoles or echinocandins, the mortality of invasive fungal infections remains unacceptably high, and studies report on mortality rates between $50 \%$ and over $80 \%$ [3,5]. Aspergillus spp., Candida spp., as well as mucormycetes are the most important pathogens causing these infections, which may occur despite potent antifungal prophylaxis [1,2]. It has become clear that the antifungal host response plays an important role determining the infection risk and outcome of IFD. For example, severe and prolonged neutropenia is the most important risk factor of IFD, and the functional activity of neutrophils, which is suppressed after HSCT, has been shown to be a prognostic factor in invasive aspergillosis [6,7]. Similarly, a $\mathrm{T}_{\mathrm{H}} 1$ response and higher numbers of natural killer (NK) cells are associated with better outcome in IFD [1,6,8]. In order to restore the impaired host immunity after allogeneic HSCT to prevent or to treat IFD, there is growing interest in adoptive immunotherapy transferring effector cells to the patient. Importantly, negative results of studies evaluating the clinical benefit of granulocyte transfusions are most likely due to insufficient number and administrations 
of granulocytes [9]. The generation of antifungal-specific $\mathrm{T}_{\mathrm{H}} 1$ cells, which have limited cross-reactivity, is still laborious and time consuming $[10,11]$.

It has been demonstrated that primary NK cells are able to kill tumor cells [12] and are active against virus-infected cells, bacteria, and a variety of fungal pathogens (reviewed in [13]). In vitro data are supported by animal studies that show, for example, that the depletion of NK cells in Aspergillus fumigatus-infected mice resulted in lower lung levels of interferon (IFN) $\gamma$ and increased fungal load [14]. In the clinical setting, the number of NK cells is associated with the risk and outcome of invasive aspergillosis in HSCT patients $[6,15]$.

Various studies have demonstrated that the benefit of an immunotherapeutic approach depends on a number of prerequisites, e.g., that the cellular product has to be rapidly accessible and consists of high cell counts, both of which are a limiting factor when using primary human NK cells $[9,16]$. Therefore, NK cell lines such as NK-92 may be considered as an ideal source for cell-based immunotherapy, as NK-92 is standardized, well-characterized, and can be cryopreserved in a GMP-compliant master cell bank, from which it can be easily and reproducibly expanded [17]. The cell line exhibits cytotoxicity against a broad spectrum of tumor targets in vitro such as various leukemia, lymphoma, and myeloma cell lines as well as primary leukemic blasts [12,18-20], and clinical studies report on excellent safety and tolerability of adoptively transferred NK-92 cells [21-23]. As it is unclear to date whether and to what extent NK-92 cells are able to damage medically important fungi, we analyzed the effect of NK-92 cell co-incubation with different species of Aspergillus, Candida, mucormycetes, and Fusarium.

\section{Materials and Methods}

\subsection{NK-92 Cell Cultivation}

Cells of the human NK cell line NK-92 (kindly provided by Torsten Tonn, Institute for Transfusion Medicine and German Red Cross Blood Donation Service North-East, Dresden, Germany) were cultivated in RPMI medium 1640 (1X) + GlutaMAX-I medium (Gibco, Paisley, UK) supplemented with 100 U/mL recombinant human interleukin (rhIL)-2 (Novartis, Basel, Switzerland) and 5\% human frozen plasma (HFP; German Red Cross Blood Donor Service Baden-Wuerttemberg-Hessen, Frankfurt, Germany).

\subsection{Assessment of the Antifungal Activity of NK-92 Cells}

The antifungal activity of NK-92 cells was tested with different species of Aspergillus $(n=4)$, Candida $(n=3)$, mucormycetes $(n=6)$, and Fusarium $(n=4)$. It was analyzed using a colorimetric assay using XTT (2,3-bis[2-methoxy-4-nitro-5-sulphenyl]2H-tetrazolium5-carboxyanilide) sodium salt (Sigma-Aldrich, Steinheim, Germany) plus coenzyme $Q_{0}$ (2,3-dimethoxy-5methyl-1,4-benzoquinone; Sigma-Aldrich), as described previously [24]. Briefly, NK-92 cells were co-incubated with the fungus for up to $6 \mathrm{~h}$ at different effectorto-target (E:T) ratios (5:1, 10:1 and 20:1) on the basis of the number of conidia or yeasts used for the formation of hyphae RPMI medium $1640(1 \times)$ + GlutaMAX-I medium (Gibco) supplemented with $100 \mathrm{U} / \mathrm{mL}$ rhIL-2 (Novartis). Fungal hyphae incubated alone served as control. NK-92 cells were lysed with sterile distilled water, and hyphae were incubated in an XTT solution $(0.25 \mathrm{mg} / \mathrm{mL})$ supplemented with $40 \mu \mathrm{g} / \mathrm{mL}$ coenzyme $Q_{0}$ at $37^{\circ} \mathrm{C}$ for $1 \mathrm{~h}$. The absorbance of the supernatant was assessed spectrophotometrically at $450 \mathrm{~nm}$ using a $690 \mathrm{~nm}$ reference. Hyphal damage was calculated as follows: hyphal damage $[\%]=(1-\mathrm{X} / \mathrm{C}) \times 100$, where $\mathrm{X}$ is the absorbance of experimental wells and $\mathrm{C}$ is the absorbance of control wells with hyphae only.

\subsection{Preparation of the Fungi}

Aspergillus fumigatus (strain AF4215) and Aspergillus terreus (clinical isolate identified by sequencing [25], provided by Cornelia Lass-Flörl, Medical University of Innsbruck, Innsbruck, Austria); Aspergillus niger complex (Aspergillus niger, clinical isolate identified by MALDI-TOF, University Hospital Frankfurt, Germany); and Aspergillus flavus (clinical 
isolate identified by MALDI-TOF, University Hospital Frankfurt, Germany) were grown on Sabouraud glucose agar plates (BD Bioscience, San Jose, CA, USA) at $37^{\circ} \mathrm{C}$ for $2-3$ days.

Lichtheimia ramosa, Lichtheimia corymbifera, Rhizopus microsporus, Rhizomucor pusillus, Cunninghamella blakesleeana, and Rhizopus arrhizus (all clinical isolates identified by sequencing, provided by Cornelia Lass-Flörl, Medical University of Innsbruck, Innsbruck, Austria) were grown on cornmeal-glucose-sucrose-yeast extract agar plates at $30^{\circ} \mathrm{C}$ for 3 to 4 days.

Fusarium oxysporum, Fusarium solani, Fusarium proliferatum, and Fusarium verticillioides (all clinical isolates identified by sequencing, provided by Cornelia Lass-Flörl, Medical University of Innsbruck, Innsbruck, Austria) were grown on potato-dextrose agar plates (PDA, BD; Dextrose PanReak AppliChem, Darmstadt, Germany) at room temperature for up to 2 weeks.

Candida albicans (ATCC 90028), Candida tropicalis (ATCC 750), and Candida dubliniensis (clinical isolate identified by MALDI-TOF and sequencing, University Hospital Frankfurt, Germany) were grown on Sabouraud glucose agar plates (BD Bioscience) at $37^{\circ} \mathrm{C}$ for 2 to 3 days.

Conidia and yeasts were harvested by gently scraping the surface of the plates, then washed in DPBS (Gibco) and filtered through a sterile $40 \mu \mathrm{m}$ cell strainer. The number of the conidia and yeasts was estimated in a Neubauer chamber (LO-Laboroptik, Friedrichsdorf, Germany). Resting conidia and yeasts were used immediately for the experiments.

Hyphae of the different fungi were prepared as described previously $[24,26,27]$. In brief, $200 \mu \mathrm{L}$ of conidia suspension of Aspergillus spp. or of mucormycetes $\left(5 \times 10^{4}\right.$ conidia per $\mathrm{mL}$ ) were plated in 96-well flat-bottom cell culture plates (Nunc, Langenselbold, Germany) and incubated in yeast nitrogen base (YNB; Sigma-Aldrich, Taufkirchen, Germany) medium at $37^{\circ} \mathrm{C}$ for $17 \mathrm{~h}$ to allow formation of hyphae. On the basis of previous results, hyphae of Candida spp. were prepared by plating yeast suspension $\left(200 \mu \mathrm{L}, 2.5 \times 10^{5}\right.$ per $\mathrm{mL}$ ) in RPMI medium containing 5\% human serum (Biochrom AG, Berlin, Germany) in 96-well flat-bottom cell culture plates (Nunc) at $37^{\circ} \mathrm{C}$ for $6 \mathrm{~h}$. Hyphae of Fusarium spp. were generated by plating $1 \times 10^{5}$ conidia per milliliter for $22 \mathrm{~h}$ (F. oxysporum, F. solani) or for $24 \mathrm{~h}$ (F. proliferatum, F. verticillioides) at $37^{\circ} \mathrm{C}$.

\subsection{Assessment of the Degranulation of NK-92 Cells}

Degranulation of NK-92 cells was evaluated as previously described with some modifications [28]. In brief, a total of $5 \times 10^{5}$ NK-92 cells were incubated in $500 \mu \mathrm{L}$ RPMI medium $1640(1 \times)+$ GlutaMAX-I medium (Gibco) in the presence or absence of A. fumigatus or R. arrhizus hyphae. After adding $5 \mu \mathrm{L}$ anti-CD107a-PE-Cy7 and $0.3 \mu \mathrm{L}$ BD GolgiStop (both BD Biosciences) and incubating at $37^{\circ} \mathrm{C}$ for $4 \mathrm{~h}$, we assessed degranulation by flow cytometry (FACSCantoII, Becton Dickinson, San Jose, CA, USA) using the following antibodies: anti-CD3-APC-Cy7, anti-CD45-FITC, and anti-CD56-APC (all BD Biosciences), and 7-amino-actinomycin-D (Beckman Coulter, Krefeld, Germany).

\subsection{Assessment of the Concentration of Soluble Molecules in the Supernatant}

Supernatants were collected after NK-92 cells had been incubated for 2, 4, and $6 \mathrm{~h}$ with or without the fungus. Levels of interferon (IFN)- $\gamma$, which is released by NK cells and modulates the immune system (limit of detection, $0.99 \mathrm{pg} / \mathrm{mL}$ ), and perforin, which mediates direct cytotoxicity (limit of detection, $11.8 \mathrm{pg} / \mathrm{mL}$ ), were analyzed by means of commercially available ELISA (Invitrogen, Thermo Fisher Scientific, Carlsbad, CA, USA) according to the manufacturer's instructions. Each experiment was performed in duplicate.

\subsection{Statistical Analyses}

Data were analyzed using GraphPad Prism (version 5.04; GraphPad Software, La Jolla, CA, USA). One-way ANOVA was used to compare multiple groups of datasets. A two-sided $p$-value of less than 0.05 was considered to be statistically significant. 


\section{Results}

\subsection{NK-92 Cells Damaged Hyphae of a Variety of Medically Important Fungi}

Our data show that NK-92 cells damaged all Aspergillus spp. tested, namely, A. fumigatus, A. terreus, A. flavus, and A. niger (Figure 1). Specifically, after $6 \mathrm{~h}$ of co-incubation at an E:T ratio of 20:1, NK-92 cells damaged [(mean \pm standard error of the mean (SEM)] $23.1 \% \pm 3.9 \%$ of $A$. fumigatus hyphae, $16.4 \% \pm 6.3 \%$ of $A$. terreus hyphae, $21.2 \% \pm 3.6 \%$ of A. flavus hyphae, and $18.7 \% \pm 5.6 \%$ of $A$. niger complex hyphae. There was no significant difference of the extent of damage between the different species.

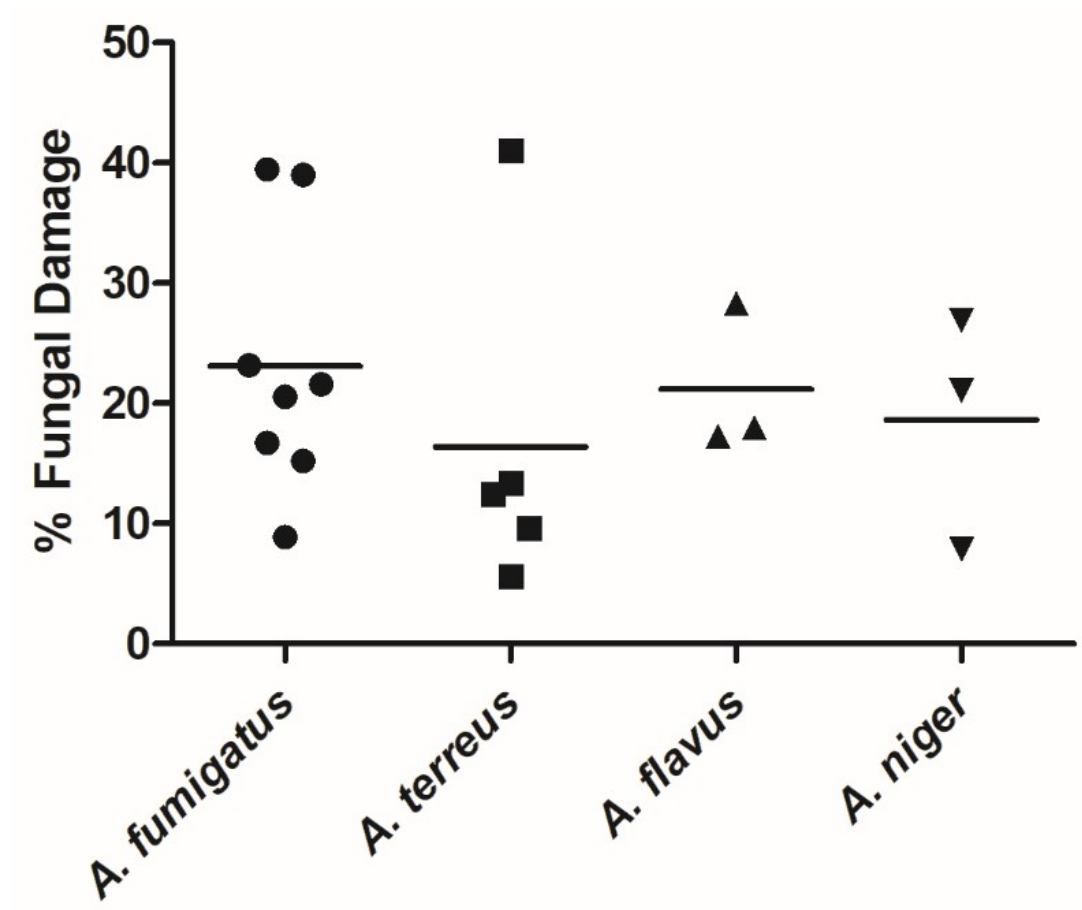

Figure 1. Hyphae of A. fumigatus, A. terreus, A. flavus, and A. niger were damaged by natural killer (NK)-92 cells. Hyphae of different species of Aspergillus were co-incubated with NK-92 cells for $6 \mathrm{~h}$ in the presence of $100 \mathrm{U} / \mathrm{mL}$ recombinant human interleukin (rhIL)-2. Hyphal damage was assessed by means of XTT (2,3-bis[2-methoxy-4-nitro-5-sulphenyl]2H-tetrazolium-5-carboxyanilide) assay. Horizontal bars represent the mean.

NK-92 cells also exhibited antifungal activity against all three Candida species tested, and damaged after 6 hours (mean \pm SEM) $37.3 \% \pm 10.9 \%, 26.0 \% \pm 9.6 \%$, and $33.3 \% \pm 5.4 \%$ of C. albicans, C. tropicalis, and C. dubliniensis hyphae, respectively (Figure 2). No significant differences in fungal damage were seen between the different species.

NK-92 cells exhibited hyphal damage on all mucormycetes tested (Figure 3). The mean hyphal damage of mucormycetes varied between $7.0 \% \pm 2.0 \%$ (mean \pm SEM; L. corymbifera) and $26.4 \% \pm 9.1 \%$ (L. ramosa). The extent of damage by NK-92 cells was comparable for L. ramosa, R. microsporus, R. pusillus, and R. arrhizus (all between $18.7 \% \pm 3.2 \%$ and $26.4 \% \pm 9.1 \%$ ), whereas the damage of L. corymbifera and C. blakesleeana was lower $(7.0 \% \pm 2.0 \%$ and $10.1 \% \pm 2.5 \%$, respectively). No significant differences of hyphal damage were detected between the various mucormycetes. 


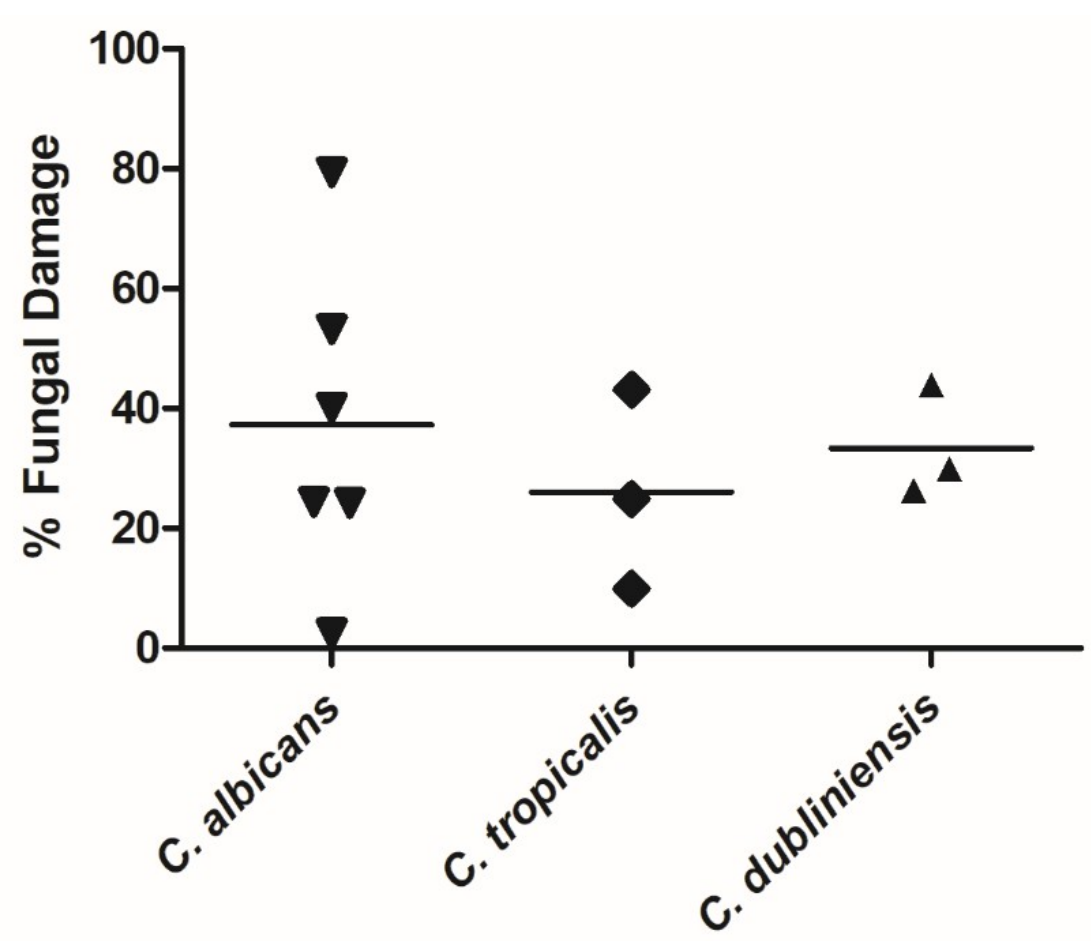

Figure 2. Hyphae of C. albicans, C. tropicalis, and C. dubliniensis were damaged by NK-92 cells. Hyphae of different species of Candida were co-incubated with NK-92 cells for 6 hours in the presence of $100 \mathrm{U} / \mathrm{mL}$ rhIL-2. Hyphal damage was assessed by means of the XTT assay. Horizontal bars represent the mean.

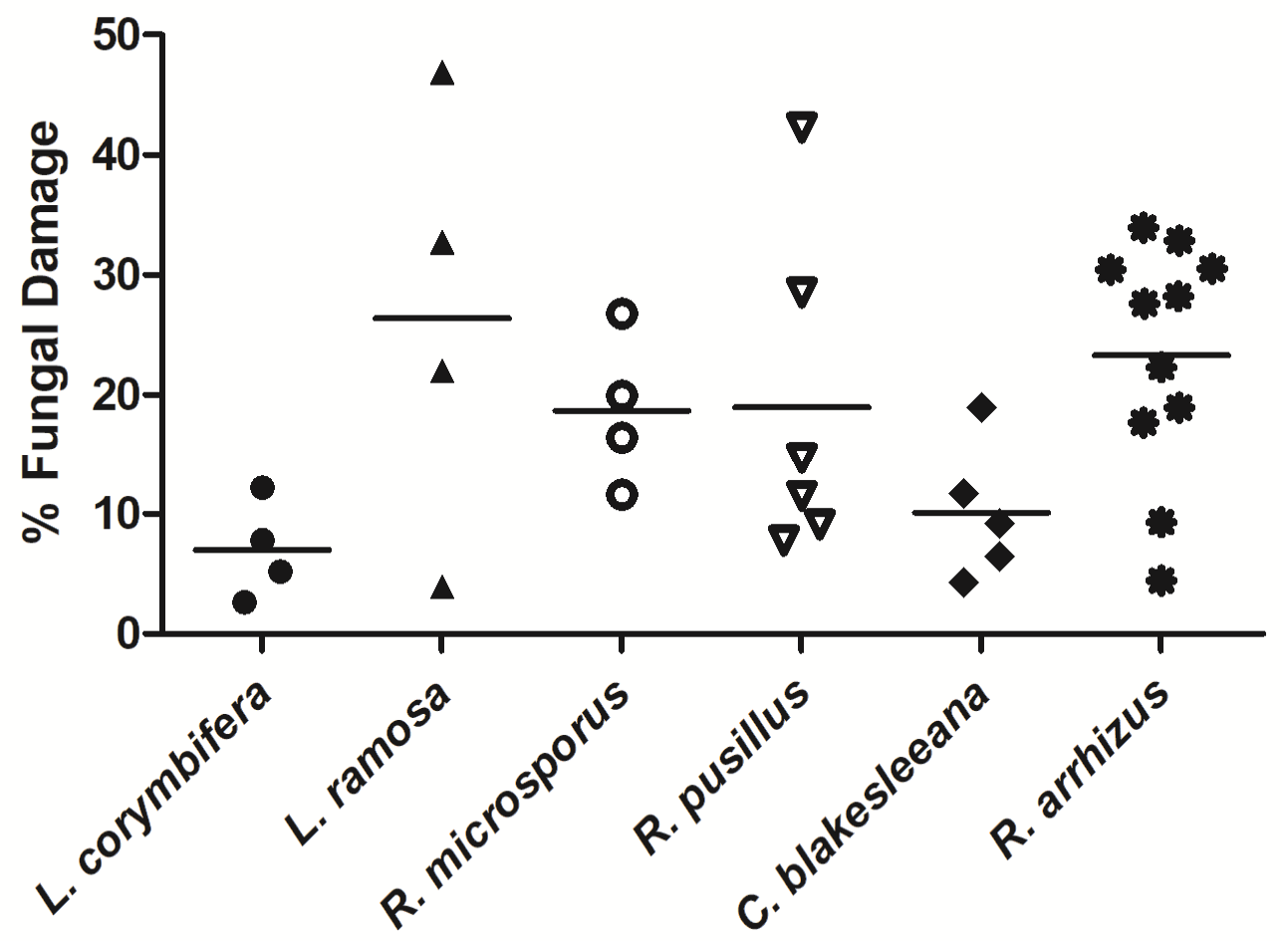

Figure 3. NK-92 cell-mediated hyphal damage of various mucormycetes. Hyphae of L. corymbifera, L. ramosa, $R$. microsporus, $R$. pusillus, C. blakesleeana, and R. arrhizus were co-incubated with NK-92 cells for 6 hours in the presence of $100 \mathrm{U} / \mathrm{mL}$ rhIL-2. Hyphal damage was assessed by means of the XTT assay. Horizontal bars represent the mean. 
Although NK-92 cells damaged all Fusarium species tested, the extent of mean damage was significantly different $(P<0.0001)$ and ranged from $31.8 \% \pm 5.1 \%$ (mean $\pm \mathrm{SEM}$; F. solani) to up to $66.7 \% \pm 3.7 \%$ (F. verticillioides) (Figure 4 ). The extent of damage of F. oxysporum and F. verticillioides hyphae by NK-92 cells was significantly higher than that of F. solani.

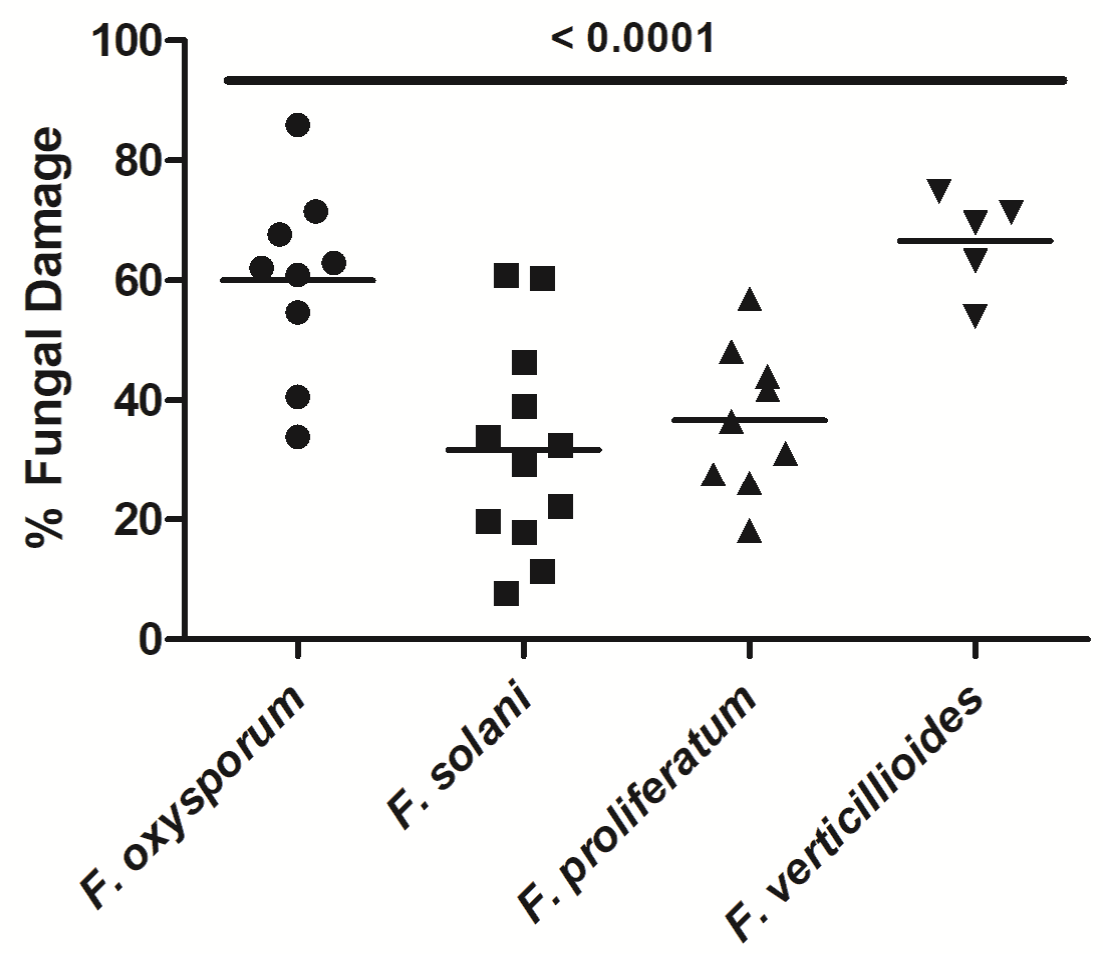

Figure 4. Hyphae of different species of Fusarium were damaged by NK-92 cells. Hyphae of F. oxysporum, F. solani, F. proliferatum, and F. verticillioides were co-incubated with NK-92 cells for $6 \mathrm{~h}$ in the presence of $100 \mathrm{U} / \mathrm{mL}$ rhIL-2. Hyphal damage was assessed by means of the XTT assay. Horizontal bars represent the mean.

3.2. The Extent of Fungal Damage of Aspergillus fumigatus, Candida flbicans, and Rhizopus frrhizus Depended on the Co-Incubation Period and Effector/Target Ratio

Analyzing the effect of NK-92 cells on A. fumigatus demonstrated that increasing E:T ratios resulted in increased fungal damage. When NK-92 cells and A. fumigatus hyphae were co-incubated for 2 hours, a statistically not significant difference was seen between the fungal damage using E:T ratios of 5:1 and 10:1, respectively, and by using an E:T ratio of 20:1 (mean \pm SEM: $0.9 \% \pm 2.6 \%$ at 5:1, $6.5 \% \pm 1.7 \%$ at $10: 1$, and $19.8 \% \pm 2.1 \%$ at $20: 1$ ) (Figure 5A). Similarly, when comparing the co-incubation periods of 2, 4, and 6 hours, the hyphal damage increased for a specific E:T ratio over time. Compared to an E:T ratio of 20:1, this increase was more pronounced for an E:T ratio of 5:1 and 10:1, but did not reach statistical significance.

Co-incubation of NK-92 cells with C. albicans for $2 \mathrm{~h}$ with increasing E:T ratios resulted in increasing mean hyphal damage (mean \pm SEM) $12.2 \% \pm 2.5 \%$ at an E:T ratio of 5:1, $18.0 \% \pm 8.7 \%$ at $10: 1$, and $25.4 \% \pm 6.1 \%$ at 20:1 (Figure 5B), which, however, was not statistically different. No major differences were seen for the hyphal damage of the fungus after 4 and 6 hours of co-incubation, independently from the E:T ratio used.

The mean damage of $R$. arrhizus by NK-92 cells varied between 14.3\% (E:T ratio 5:1, $4 \mathrm{~h}$ co-incubation) and $26.6 \%$ (E:T ratio 10:1, $6 \mathrm{~h}$ co-incubation), and did not demonstrate a specific pattern with increasing fungal damage in relation to increasing E:T ratios or longer periods of co-incubation (Figure 5C). 
A

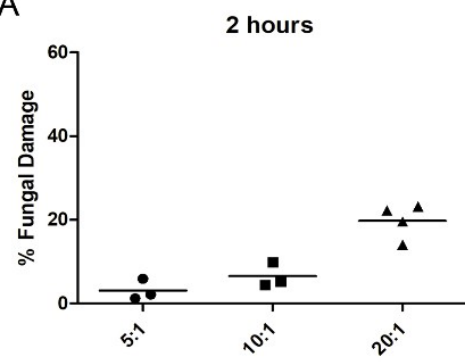

B

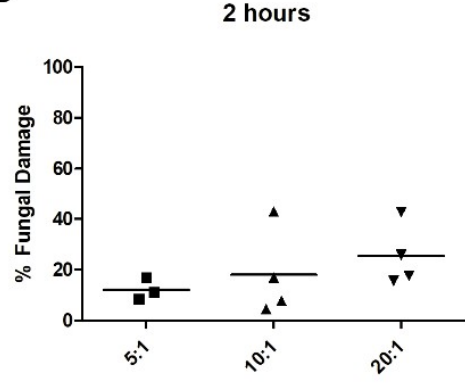

C

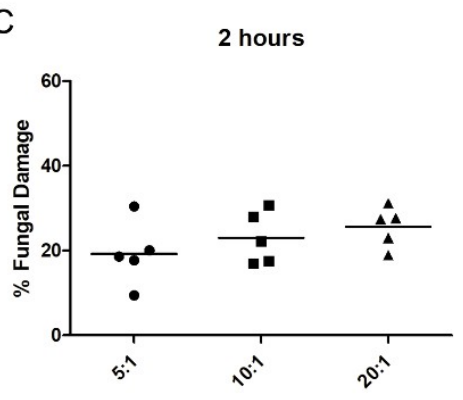

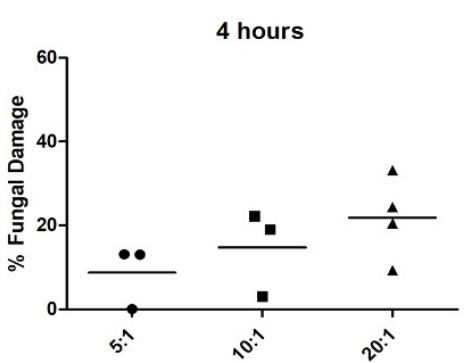

NK-92 vs. Aspergillus fumigatus

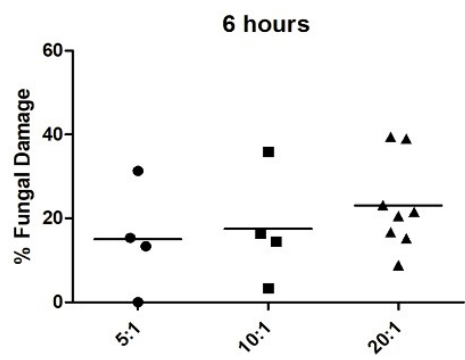

4 hours

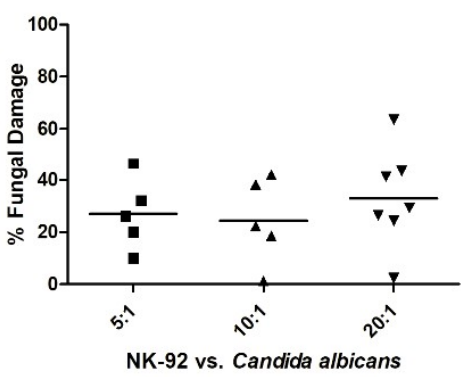

4 hours

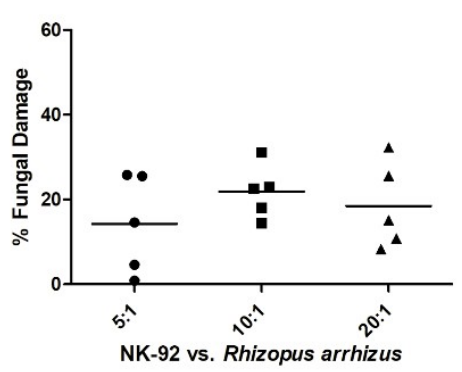

6 hours

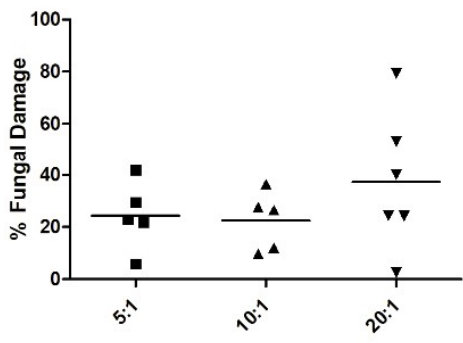

6 hours

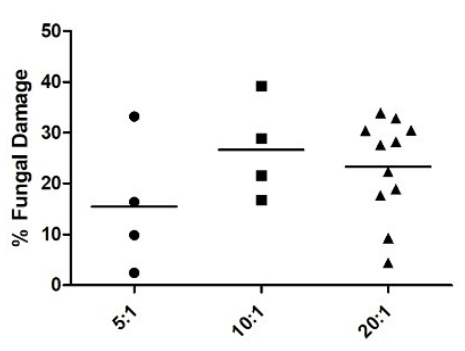

Figure 5. Damage of hyphae of A. fumigatus (A), C. albicans (B), or R. arrhizus (C) by NK-92 cells. Hyphae of the specific fungi were co-incubated with NK-92 cells at different effector-to-target (E:T) ratios (5:1, 10:1, and 20:1) in the presence of $100 \mathrm{U} / \mathrm{mL}$ rhIL-2 for 2 (left), 4 (center), and 6 hours (right). Fungal damage was assessed by means of the XTT assay. Horizontal bars represent the mean.

\subsection{Assessment of Perforin Levels in the Supernatant and of the Degranulation Marker CD107a on the Surface of NK-92 Cells}

When adding a fungal pathogen to NK-92 cells, we found measured perforin levels to be lower compared to NK-92 cells incubated alone (Figure 6A-C). Although statistically not significant, this difference was more pronounced after $6 \mathrm{~h}$ for all fungi of co-incubation than after 2 or $4 \mathrm{~h}$. For example, co-incubation of NK-92 cells for $2 \mathrm{~h}$ with $A$. fumigatus at E:T ratios of 5:1, 10:1, and 20:1, resulted in perforin levels of (mean $\pm \mathrm{SEM}$ ) $765.2 \mathrm{pg} / \mathrm{mL} \pm 64.0 \mathrm{pg} / \mathrm{mL}, 827.3 \mathrm{pg} / \mathrm{mL} \pm 43.3 \mathrm{pg} / \mathrm{mL}$, and $877.6 \mathrm{pg} / \mathrm{mL}$ $\pm 40.5 \mathrm{pg} / \mathrm{mL}$, respectively, whereas perforin levels of NK-92 cells incubated alone were $913.9 \mathrm{pg} / \mathrm{mL} \pm 43.9 \mathrm{pg} / \mathrm{mL}, 1076.0 \mathrm{pg} / \mathrm{mL} \pm 147.5 \mathrm{pg} / \mathrm{mL}$, and $1230.0 \mathrm{pg} / \mathrm{mL} \pm$ $173.0 \mathrm{pg} / \mathrm{mL}$, respectively. Co-incubation for $6 \mathrm{~h}$ with A. fumigatus at E:T ratios of 5:1, 10:1, and 20:1 led to perforin levels of $1002.9 \mathrm{pg} / \mathrm{mL} \pm 115.4 \mathrm{pg} / \mathrm{mL}, 970.5 \mathrm{pg} / \mathrm{mL} \pm 46.6 \mathrm{pg} / \mathrm{mL}$, and $1098.2 \mathrm{pg} / \mathrm{mL} \pm 116.0 \mathrm{pg} / \mathrm{mL}$, respectively, compared to corresponding perforin levels of $1270.2 \mathrm{pg} / \mathrm{mL} \pm 219.5 \mathrm{pg} / \mathrm{mL}, 1597.0 \mathrm{pg} / \mathrm{mL} \pm 315.4 \mathrm{pg} / \mathrm{mL}$, and $1507.3 \mathrm{pg} / \mathrm{mL} \pm$ $242.8 \mathrm{pg} / \mathrm{mL}$, respectively, when NK-92 cells were incubated alone (Figure 6A). A similar pattern was seen when NK-92 cells were co-incubated with $R$. arrhizus, whereas $C$. albicans altered the perforin levels not before $6 \mathrm{~h}$ of co-incubation (Figure $6 \mathrm{~B}, \mathrm{C}$ ). 
A
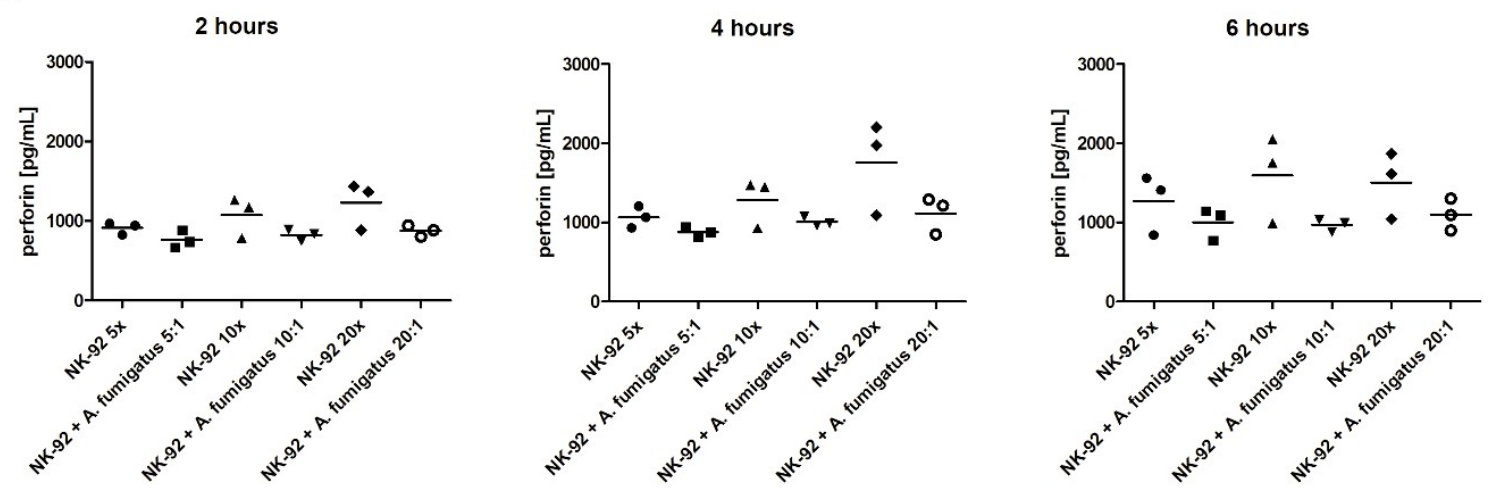

B
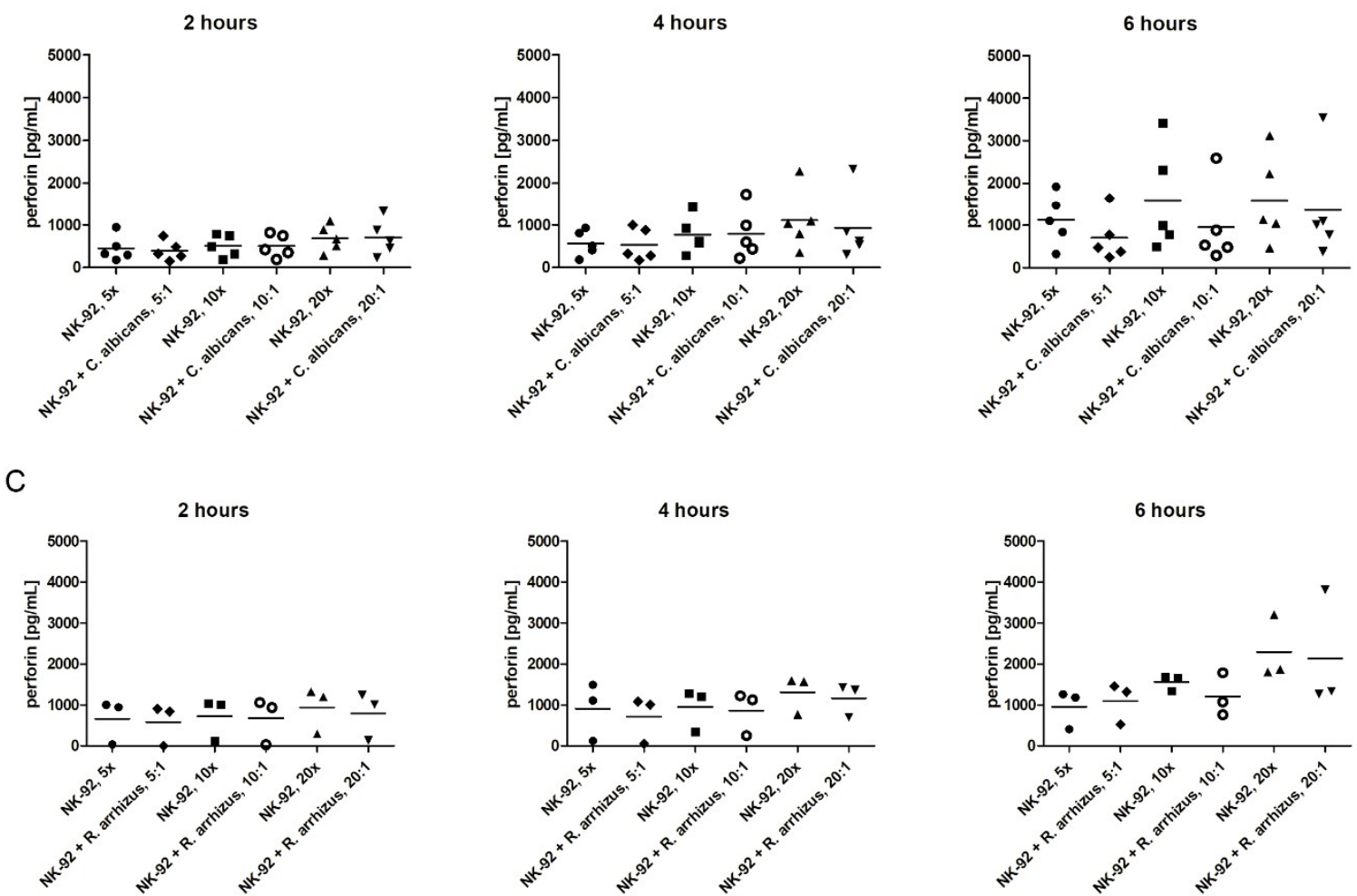

Figure 6. Concentration of perforin in the supernatant when NK-92 cells were incubated alone (empty boxes) or were co-incubated with hyphae of A. fumigatus (A), C. albicans (B), or R. arrhizus (C) (shaded boxes). Perforin levels were assessed by ELISA. Horizontal bars represent the mean.

In contrast to the slightly decreased perforin levels, there was an upregulation of the surface expression of the degranulation marker CD107a upon co-incubation of NK-92 cells with hyphae of A. fumigatus and R. arrhizus (Figure S1).

\subsection{Assessment of IFN- $\gamma$ Levels in the Supernatant}

When NK-92 cells were co-incubated with $A$. fumigatus, IFN- $\gamma$ levels in the supernatant were lower at all time points analyzed compared to those of NK-92 cells incubated alone, although these differences were statistically not significant (Figure 7A). For example, coincubation of NK-92 cells and the fungal pathogen for $6 \mathrm{~h}$ at E:T ratios of 5:1, 10:1, and 20:1 resulted in IFN- $\gamma$ levels of $19.2 \mathrm{pg} / \mathrm{mL} \pm 15.8 \mathrm{pg} / \mathrm{mL}, 31.7 \mathrm{pg} / \mathrm{mL} \pm 28.6 \mathrm{pg} / \mathrm{mL}$, and $25.0 \mathrm{pg} / \mathrm{mL} \pm 19.5 \mathrm{pg} / \mathrm{mL}$, respectively, whereas corresponding IFN- $\gamma$ levels of NK-92 cells incubated alone were $39.0 \mathrm{pg} / \mathrm{mL} \pm 34.2 \mathrm{pg} / \mathrm{mL}, 56.4 \mathrm{pg} / \mathrm{mL} \pm 52.2 \mathrm{pg} / \mathrm{mL}$, and $77.9 \mathrm{pg} / \mathrm{mL} \pm 69.3 \mathrm{pg} / \mathrm{mL}$, respectively. The decrease in IFN- $\gamma$ levels was also observed 
after 4 and $6 \mathrm{~h}$ of co-incubation of NK-92 cells with C. albicans (Figure 7B), and after $6 \mathrm{~h}$ of co-incubation of NK-92 cells with $R$. arrhizus (Figure 7C).

A
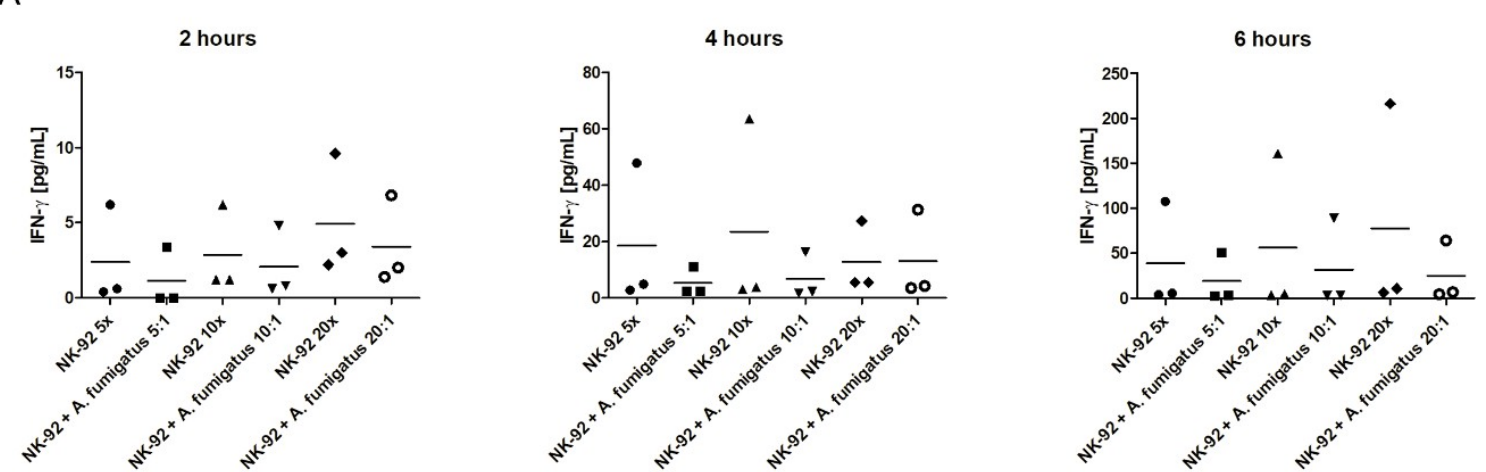

B
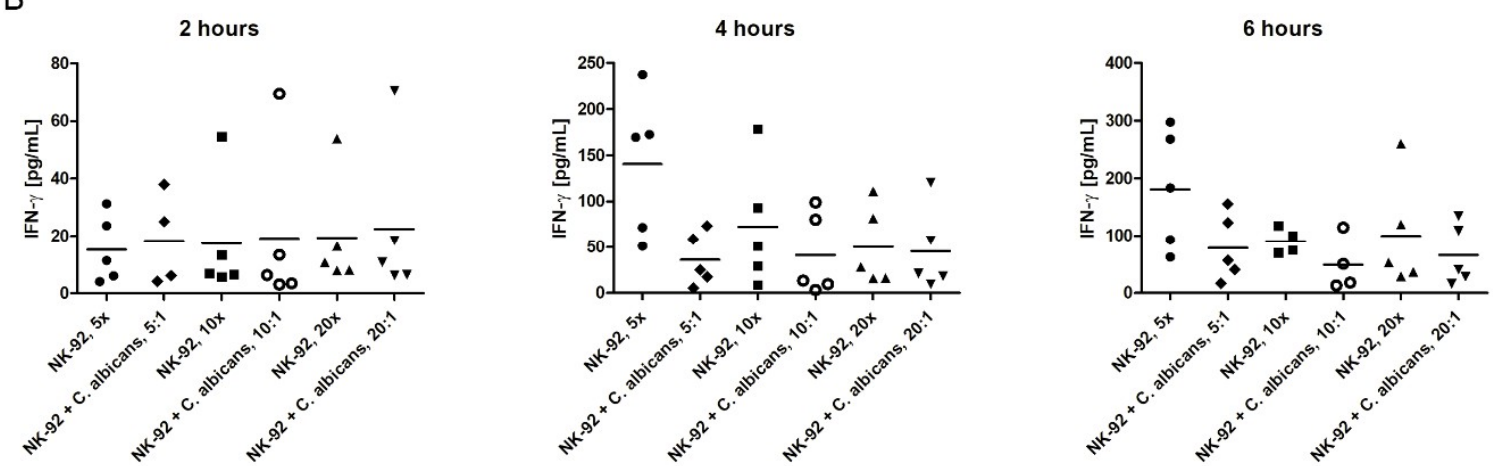

C
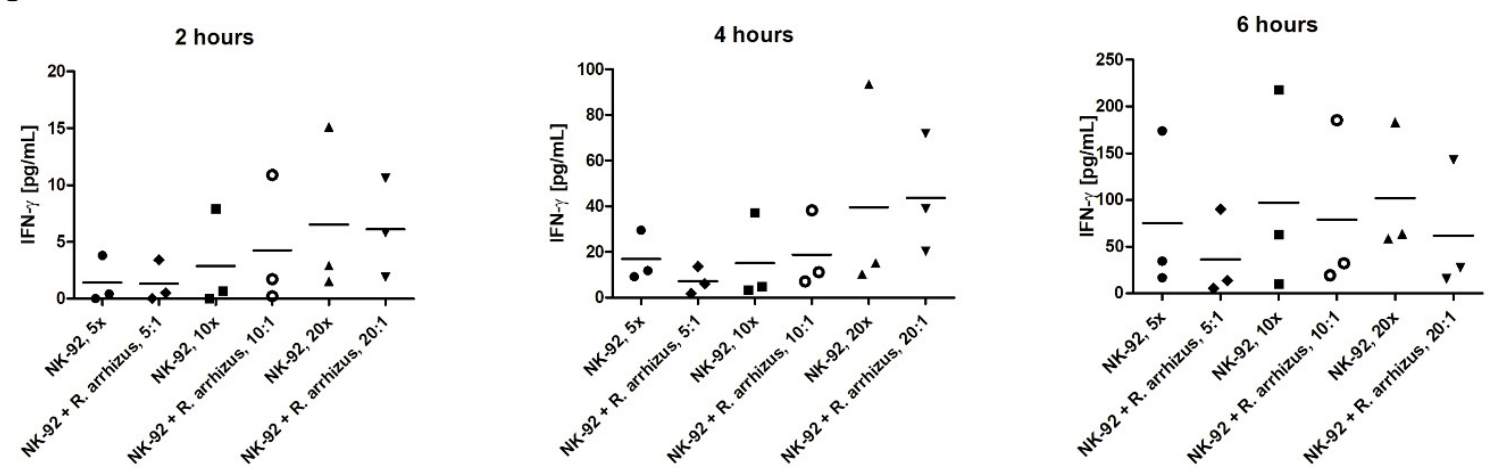

Figure 7. Concentration of interferon (IFN)- $\gamma$ in the supernatant when NK-92 cells were incubated alone (empty boxes) or were co-incubated with hyphae of $A$. fumigatus (A), C. albicans (B), or R. arrhizus (C) (shaded boxes). IFN- $\gamma$ levels were assessed by ELISA. Horizontal bars represent the mean.

\section{Discussion}

Despite the availability of new and potent antifungal compounds such as broadspectrum triazoles or the new class of echinocandins, morbidity and mortality of IFD remains unacceptably high, particularly in allogeneic HSCT recipients. For example, a single-center retrospective study including 404 patients undergoing HSCT reported a 1year cumulative incidence of IFD of $11 \%$ despite mold-active antifungal prophylaxis [1]. The non-relapse mortality was $16 \%$ in patients who did not develop IFD, but reached $40 \%$ in those in whom IFD occurred. As therapy-induced alterations of the number and function of phagocytes, NK cells or the cellular immune system are known to increase the risk for IFD and are associated with poor outcome $[1,6,8]$; there is growing interest in adoptive immunotherapeutic strategies for restoring immunity to prevent or to treat 
IFD. Unfortunately, to date, clinical studies have failed to demonstrate the benefit of immunotherapeutic approaches in infectious complications. This is due, at least in part, to the fact that effector cells are often available in limited numbers only and are not timely accessible, as the generation of the immunotherapeutic cellular product such as fungalspecific T cells requires donor cells and is laborious and time-consuming [9-11]. Therefore, standardized and well-characterized cell lines would be an ideal source for adoptive immunotherapy in patients with IFD.

Although it has been shown that NK-92 cells are able to kill tumor cells [12] and are active against virus-infected cells [29-31], the ability of NK-92 cells to damage fungi has not been investigated to date. Therefore, one of our main findings was the observation that NK-92 cells exhibit fungal damage on all medically important fungi tested, namely, on different species of Aspergillus, Candida, mucormycetes, and Fusarium. The extent of fungal damage significantly differed between the species of Fusarium, whereas it was comparable across different species of Aspergillus, mucormycetes, and Candida. Results of experiments performed in the identical setting as the present studies demonstrate not only a comparable anti-Aspergillus and anti-mucormycete activity of NK-92 cells and primary human NK cells, but also an anti-Aspergillus activity in the range of that seen in this setting by pharmacological dosages of the antifungal compounds caspofungin or voriconazole [21,23,24,32]. Studies in freshly isolated NK cells and polymorphonuclear leukocytes have suggested that the extent of fungal damage not only depends on the fungal species, but also on fungal growth characteristics, with higher damage in lower biomass [27,33]. For the clinical setting, these data imply that adoptive immunotherapy using NK-92 cells should start as early as possible with a maximum tolerated number of NK92 cells. Clinical studies evaluating NK-92 cells as immunotherapy against a malignancy reported that dosages up to $10^{10}$ cells per square meter were well tolerated with no or minimal toxicities [21-23]. In addition, similar to the fact that most patients with proven or probable IFD receive one or more antifungal drugs over weeks and months, it might be necessary in the clinical situation to repeat NK-92 immunotherapy multiple times. To this end, the rapid availability of sufficient number of cells and the possibility to administer the cells multiple times over weeks favors NK-92 cells compared to primary human NK cells for antifungal immunotherapy, in particular as the antifungal activity in vitro is comparable.

A. fumigatus is damaged by purified human perforin, and blocking perforin-mediated toxicity by concanamycin A significantly decreases fungal damage by IL-2 pre-stimulated human NK cells, which clearly indicates that NK cell-derived perforin plays an important role in the antifungal activity of NK cells [24]. Whereas previous studies with primary human NK cells demonstrated a direct correlation of the upregulation of the degranulation marker CD107a and increasing concentrations of perforin in the supernatant [26,34], we found a slight, but not significant decrease of the perforin levels in the supernatant of NK-92 cells. Perforin reduces the metabolic activity of hyphae of A. fumigatus [24], R. arrhizus [26], and of C. albicans [35], inhibits hyphal elongation of C. albicans [35], and growth of Cryptococcus neoformans [36]. However, the exact mechanism of perforin-mediated damage of fungal cells is not clear to date. Previous data have shown that in human NK cells, A. fumigatus downregulates mRNA levels of perforin, but increases both intracellular concentration and the release of the molecule, resulting in higher extracellular perforin concentrations [37]. This is in contrast to the present results, which demonstrate that co-incubation of NK-92 cells with A. fumigatus, C. albicans, or R. arrhizus did not lead to an increase of perforin levels in the supernatant. The fact that increased fungal damage was observed although the levels of perforin in the supernatant did not increase may be explained by the fact that other NK-92-derived molecules exhibit direct antifungal activity or that there is a consumption of the molecule while damaging the fungi. We did not assess the levels of granulysin and granzyme B in the supernatant, but it is important to note that granzyme B did not exhibit any effect against $C$. albicans or enhanced the antifungal activity of perforin [34].

Beside the direct NK cell-mediate fungal damage, soluble factors released by NK cells play an important role in the regulation of the antifungal host response. For example, NK 
cell-derived IFN- $\gamma$ stimulates the migration of phagocytes and enhances their phagocytic and oxidative killing activity of A. fumigatus [38], and is a signature cytokine of protective $\mathrm{T}_{\mathrm{H}} 1$ response [38-40]. In a mouse model, it was demonstrated that the depletion of NK cells in A. fumigatus-infected animals resulted in lower lung levels of IFN- $\gamma$ and increased fungal load [14]. The present data show that co-incubation of NK-92 cells with hyphae of A. fumigatus, C. albicans, or R. arrhizus decreased the concentration of IFN- $\gamma$ in the supernatant compared to that of NK-92 alone; however, when comparing the different fungi, there was no clear pattern with regard to the extent and kinetics. The present results are corroborating a study on human NK cells that demonstrated that incubation of IL-2 stimulated primary NK cells with hyphae of A. fumigatus resulted in intracellular accumulation of the IFN- $\gamma$ protein but reduction of its concentration in the supernatant [37]. The mechanisms causing the extracellular decrease of IFN- $\gamma$ are unclear to date, but is the focus of our current research, which might help to improve adoptive immunotherapeutic strategies. Another study reported recently that IFN- $\gamma$ levels in the supernatant of NK cells co-incubated with K562 tumor cells decreased when adding A. fumigatus [41]. The authors of this study speculated that this was due to an exhaustion phenotype of the cells. However, whether the reduction of extracellular IFN- $\gamma$ levels in the presence of fungi ultimately results in an impaired antifungal host response in vivo or are a protecting host effect against hyper-inflammation leading to tissue damage will be a matter of future research.

Despite the potential advantages of the NK-92 cell line such as the rapid availability of high counts of standardized and well-characterized effector cells, a number of potentially important drawbacks for the clinical setting have to be mentioned. First, the NK-92 cell line is derived from a NK cell lymphoma and has the potential risk of uncontrolled proliferation. Therefore, irradiation is mandatory prior to adoptive immunotherapy, but limits the survival and function of the cells. There also are major concerns regarding safety, but an early study performed in Germany, which included 15 patients including children (patients' ages were 9-71 years) with advanced, treatment-resistant malignancies who received two infusions of NK-92 cells did not report a negative effect of NK-92 cells on blood cell counts or renal and hepatic function [21]. Similarly, in an ongoing phase I clinical trial [CAR2BRAIN (NCT03383978, clinicaltrials.gov (accessed on 1 February 2021))], which has undergone rigorous evaluation by regulatory authorities as well by an ethical committee, NK-92 cells are administered intracranially as a therapeutic approach in patients with recurrent or refractory ErbB2-positive glioblastoma. In the first cohort of nine patients treated until the end of 2019, no adverse events related to the NK-92 lymphoma cells occurred (personal communication by Michael Burger). In addition, NK-92 cells depend on IL-2, and repeated IL-2 injections raise concerns regarding toxicity [18,42]. Interestingly, a preclinical study reported on the transduction of NK-92 cells with lentiviral vectors encoding human IL-15, which resulted in a predominantly intracellular expression of the cytokine, and proliferation and cytotoxicity of the cells in the absence of IL-2 [43]. It is also important to mention that other cell lines such as the KHYG-1 cell line, which is derived from NK leukemia, or the cell line NKL [44], which is biologically and functionally very similar to primary NK cells, may be superior compared to NK-92 cells for adoptive immunotherapy of IFD, but the antimicrobial activity of these cell lines is unclear to date and has to be evaluated prior to clinical use.

In conclusion, our data demonstrate that NK-92 cells exhibit antifungal activity against a broad range of fungal pathogens such as Aspergillus spp., Candida spp., mucormycetes, and Fusarium spp. and may be suitable as a standardized and rapidly available cell product for adoptive immunotherapy of IFD in allogeneic HSCT patients, but data of animal models are warranted prior to clinical trials.

Supplementary Materials: The following are available online at https:/ /www.mdpi.com/2309-608 X/7/2/144/s1, Figure S1: Hyphae of A. fumigatus (left) and R. arrhizus (right) induce degranulation of NK-92 cells. 
Author Contributions: All authors have significantly contributed to the manuscript by designing the study (S.S., M.L., M.H., T.L.), performing the experiments (S.S.), and analyzing the data (S.S., M.L., M.H., T.L.). All authors have read and agreed to the published version of the manuscript.

Funding: This research received funding from the Madeleine Schickedanz-KinderKrebs-Stiftung.

Data Availability Statement: The data that support the findings of this study are available from the corresponding author upon reasonable request.

Acknowledgments: We would like to thank Asuman Demir and Frauke Röger for their excellent technical assistance. We also would like to thank Emilia Salzmann-Manrique for her assistance in the statistical analysis.

Conflicts of Interest: All other authors (S.S., M.L., M.H., T.L.) do not have conflicts of interest regarding the content of this manuscript.

\section{References}

1. Montesinos, P.; Rodríguez-Veiga, R.; Boluda, B.; Martínez-Cuadrón, D.; Cano, I.; Lancharro, A.; Sanz, J.; Arilla, M.J.; López-Chuliá, F.; Navarro, I.; et al. Incidence and risk factors of post-engraftment invasive fungal disease in adult allogeneic hematopoietic stem cell transplant recipients receiving oral azoles prophylaxis. Bone Marrow Transplant. 2015, 50, 1465-1472. [CrossRef]

2. Lehrnbecher, T.; Schöning, S.; Poyer, F.; Georg, J.; Becker, A.; Gordon, K.; Attarbaschi, A.; Groll, A.H. Incidence and Outcome of Invasive Fungal Diseases in Children With Hematological Malignancies and/or Allogeneic Hematopoietic Stem Cell Transplantation: Results of a Prospective Multicenter Study. Front. Microbiol. 2019, 10, 681. [CrossRef]

3. Neofytos, D.; Horn, D.; Anaissie, E.; Steinbach, W.; Olyaei, A.; Fishman, J.; Pfaller, M.; Chang, C.; Webster, K.; Marr, K. Epidemiology and outcome of invasive fungal infection in adult hematopoietic stem cell transplant recipients: Analysis of multicenter prospective antifungal therapy (PATH) alliance registry. Clin. Infect. Dis. 2009, 48, 265-273. [CrossRef] [PubMed]

4. Stanzani, M.; Lewis, R. Development and Applications of Prognostic Risk Models in the Management of Invasive Mold Disease. J. Fungi 2018, 4, 141. [CrossRef] [PubMed]

5. Drgona, L.; Khachatryan, A.; Stephens, J.; Charbonneau, C.; Kantecki, M.; Haider, S.; Barnes, R. Clinical and economic burden of invasive fungal diseases in Europe: Focus on pre-emptive and empirical treatment of Aspergillus and Candida species. Eur. J. Clin. Microbiol. Infect. Dis. 2014, 33, 7-21. [CrossRef] [PubMed]

6. Stuehler, C.; Kuenzli, E.; Jaeger, V.K.; Baettig, V.; Ferracin, F.; Rajacic, Z.; Kaiser, D.; Bernardini, C.; Forrer, P.; Weisser, M.; et al. Immune Reconstitution After Allogeneic Hematopoietic Stem Cell Transplantation and Association With Occurrence and Outcome of Invasive Aspergillosis. J. Infect. Dis. 2015, 212, 959-967. [CrossRef] [PubMed]

7. Fisher, B.T.; Robinson, P.D.; Lehrnbecher, T.; Steinbach, W.J.; Zaoutis, T.E.; Phillips, B.; Sung, L. Risk Factors for Invasive Fungal Disease in Pediatric Cancer and Hematopoietic Stem Cell Transplantation: A Systematic Review. J. Pediatric Infect. Dis. Soc. 2018, 7, 191-198. [CrossRef]

8. Hebart, H.; Bollinger, C.; Fisch, P.; Sarfati, J.; Meisner, C.; Baur, M.; Loeffler, J.; Monod, M.; Latgé, J.P.; Einsele, H. Analysis of T-cell responses to Aspergillus fumigatus antigens in healthy individuals and patients with hematologic malignancies. Blood 2002, 100, 4521-4528. [CrossRef]

9. Seidel, M.G.; Peters, C.; Wacker, A.; Northoff, H.; Moog, R.; Boehme, A.; Silling, G.; Grimminger, W.; Einsele, H. Randomized phase III study of granulocyte transfusions in neutropenic patients. Bone Marrow Transplant. 2008, 42, 679-684. [CrossRef] [PubMed]

10. Castillo, P.; Wright, K.E.; Kontoyiannis, D.P.; Walsh, T.; Patel, S.; Chorvinsky, E.; Bose, S.; Hazrat, Y.; Omer, B.; Albert, N.; et al. A New Method for Reactivating and Expanding T Cells Specific for Rhizopus oryzae. Mol. Ther. Methods Clin. Dev. 2018, 9 , 305-312. [CrossRef]

11. Tramsen, L.; Schmidt, S.; Boenig, H.; Latgé, J.P.; Lass-Flörl, C.; Roeger, F.; Seifried, E.; Klingebiel, T.; Lehrnbecher, T. Clinicalscale generation of multi-specific anti-fungal T cells targeting Candida, Aspergillus and mucormycetes. Cytotherapy 2013, 15, 344-351. [CrossRef]

12. Yan, Y.; Steinherz, P.; Klingemann, H.G.; Dennig, D.; Childs, B.H.; McGuirk, J.; O’Reilly, R.J. Antileukemia activity of a natural killer cell line against human leukemias. Clin. Cancer Res. 1998, 4, 2859-2868. [PubMed]

13. Schmidt, S.; Tramsen, L.; Rais, B.; Ullrich, E.; Lehrnbecher, T. Natural killer cells as a therapeutic tool for infectious diseases -Current status and future perspectives. Oncotarget 2018, 9, 20891-20907. [CrossRef] [PubMed]

14. Park, S.J.; Hughes, M.A.; Burdick, M.; Strieter, R.M.; Mehrad, B. Early NK cell-derived IFN- $\gamma$ is essential to host defense in neutropenic invasive aspergillosis. J. Immunol. 2009, 182, 4306-4312. [CrossRef]

15. Fernández-Ruiz, M.; López-Medrano, F.; San Juan, R.; Allende, L.M.; Paz-Artal, E.; Aguado, J.M. Low Natural Killer Cell Counts and Onset of Invasive Fungal Disease After Solid Organ Transplantation. J. Infect. Dis. 2016, 213, 873-874. [CrossRef]

16. Soe, W.M.; Hui, J.; Lim, J.; Williams, D.L.; Goh, J.G.; Tan, Z.; Sam, Q.H.; Chotirmall, S.H.; A'tikah Binte, N.; Ali, M.; et al. Using Expanded Natural Killer Cells as Therapy for Invasive Aspergillosis. J. Fungi 2020, 6, 231. [CrossRef] [PubMed]

17. Tonn, T.; Becker, S.; Esser, R.; Schwabe, D.; Seifried, E. Cellular Immunotherapy of Malignancies Using the Clonal Natural Killer Cell Line NK-92. J. Hematother. Stem Cell Res. 2001, 10, 535-544. [CrossRef] 
18. Tam, Y.K.; Miyagawa, B.; Ho, V.C.; Klingemann, H.G. Immunotherapy of malignant melanoma in a SCID mouse model using the highly cytotoxic natural killer cell line NK-92. J. Hematother. 1999, 8, 281-290. [CrossRef]

19. Gong, J.H.; Maki, G.; Klingemann, H.G. Characterization of a human cell line (NK-92) with phenotypical and functional characteristics of activated natural killer cells. Leukemia 1994, 8, 652-658.

20. Klingemann, H.G.; Wong, E.; Maki, G. A cytotoxic NK-cell line (NK-92) for ex vivo purging of leukemia from blood. Biol. Blood Marrow Transplant. 1996, 2, 68-75.

21. Tonn, T.; Schwabe, D.; Klingemann, H.G.; Becker, S.; Esser, R.; Koehl, U.; Suttorp, M.; Seifried, E.; Ottmann, O.G.; Bug, G. Treatment of patients with advanced cancer with the natural killer cell line NK-92. Cytotherapy 2013, 15, 1563-1570. [CrossRef]

22. Arai, S.; Meagher, R.; Swearingen, M.; Myint, H.; Rich, E.; Martinson, J.; Klingemann, H. Infusion of the allogeneic cell line NK-92 in patients with advanced renal cell cancer or melanoma: A phase I trial. Cytotherapy 2008, 10, 625-632. [CrossRef]

23. Boyiadzis, M.; Agha, M.; Redner, R.L.; Sehgal, A.; Im, A.; Hou, J.Z.; Farah, R.; Dorritie, K.A.; Raptis, A.; Lim, S.H.; et al. Phase 1 clinical trial of adoptive immunotherapy using "off-the-shelf" activated natural killer cells in patients with refractory and relapsed acute myeloid leukemia. Cytotherapy 2017, 19, 1225-1232. [CrossRef] [PubMed]

24. Schmidt, S.; Tramsen, L.; Hanisch, M.; Latgé, J.-P.; Huenecke, S.; Koehl, U.; Lehrnbecher, T. Human natural killer cells exhibit direct activity against Aspergillus fumigatus hyphae, but not against resting conidia. J. Infect. Dis. 2011, 203, 430-435. [CrossRef]

25. Raja, H.A.; Miller, A.N.; Pearce, C.J.; Oberlies, N.H. Fungal Identification Using Molecular Tools: A Primer for the Natural Products Research Community. J. Nat. Prod. 2017, 80, 756-770. [CrossRef] [PubMed]

26. Schmidt, S.; Tramsen, L.; Perkhofer, S.; Lass-Flörl, C.; Hanisch, M.; Roger, F.; Klingebiel, T.; Koehl, U.; Lehrnbecher, T. Rhizopus oryzae hyphae are damaged by human natural killer (NK) cells, but suppress NK cell mediated immunity. Immunobiology 2013, 218, 939-944. [CrossRef] [PubMed]

27. Schmidt, S.; Schneider, A.; Demir, A.; Lass-Flörl, C.; Lehrnbecher, T. Natural killer cell-mediated damage of clinical isolates of mucormycetes. Mycoses 2016, 59, 34-38. [CrossRef]

28. Aktas, E.; Kucuksezer, U.C.; Bilgic, S.; Erten, G.; Deniz, G. Relationship between CD107a expression and cytotoxic activity. Cell. Immunol. 2009, 254, 149-154. [CrossRef]

29. Zhang, T.; Li, Y.; Wang, Y.-J.; Wang, X.; Young, M.; Douglas, S.D.; Ho, W.-Z. Natural killer cell inhibits human immunodeficiency virus replication in chronically infected immune cells. Antiviral Res. 2007, 73, 132-139. [CrossRef]

30. Iversen, A.; Norris, P.S.; Ware, C.F.; Benedict, C.A. Human NK cells inhibit cytomegalovirus replication through a noncytolytic mechanism involving lymphotoxin-dependent induction of IFN-beta. J. Immunol. 2005, 175, 7568-7574. [CrossRef]

31. Li, Y.; Zhang, T.; Ho, C.; Orange, J.S.; Douglas, S.D.; Ho, W.-Z. Natural killer cells inhibit hepatitis C virus expression. J. Leukoc. Biol. 2004, 76, 1171-1179. [CrossRef]

32. Schmidt, S.; Schubert, R.; Tramsen, L.; Lehrnbecher, T. Impact of antifungal compounds on viability and anti-Aspergillus activity of human natural killer cells. Antimicrob. Agents Chemother. 2019, 63. [CrossRef]

33. Antachopoulos, C.; Demchok, J.P.; Roilides, E.; Walsh, T.J. Fungal biomass is a key factor affecting polymorphonuclear leucocyteinduced hyphal damage of filamentous fungi. Mycoses 2009, 53, 321-328. [CrossRef] [PubMed]

34. Voigt, J.; Hünniger, K.; Bouzani, M.; Jacobsen, I.D.; Barz, D.; Hube, B.; Löffler, J.; Kurzai, O. Human Natural Killer Cells Acting as Phagocytes Against Candida albicans and Mounting an Inflammatory Response That Modulates Neutrophil Antifungal Activity. J. Infect. Dis. 2014, 209, 616-626. [CrossRef]

35. Hellwig, D.; Voigt, J.; Bouzani, M.; Löffler, J.; Albrecht-Eckardt, D.; Weber, M.; Brunke, S.; Martin, R.; Kurzai, O.; Hünniger, K. Candida albicans Induces Metabolic Reprogramming in Human NK Cells and Responds to Perforin with a Zinc Depletion Response. Front. Microbiol. 2016, 7, 750. [CrossRef] [PubMed]

36. Ma, L.L.; Wang, C.L.C.; Neely, G.G.; Epelman, S.; Krensky, A.M.; Mody, C.H. NK cells use perforin rather than granulysin for anticryptococcal activity. J. Immunol. 2004, 173, 3357-3365. [CrossRef]

37. Schneider, A.; Blatzer, M.; Posch, W.; Schubert, R.; Lass-Flörl, C.; Schmidt, S.; Lehrnbecher, T. Aspergillus fumigatus responds to natural killer (NK) cells with upregulation of stress related genes and inhibits the immunoregulatory function of NK cells. Oncotarget 2016, 7, 71062-71071. [CrossRef]

38. Gil-lamaignere, C.; Simitsopoulou, M.; Roilides, E.; Maloukou, A.; Winn, R.M.; Walsh, T.J. Interferon- $\gamma$ and GranulocyteMacrophage Colony-Stimulating Factor Augment the Activity of Polymorphonuclear Leukocytes against Medically Important Zygomycetes. J. Infect. Dis. 2005, 191, 1180-1187. [CrossRef]

39. Lehrnbecher, T.; Kalkum, M.; Champer, J.; Tramsen, L.; Schmidt, S.; Klingebiel, T. Immunotherapy in Invasive Fungal InfectionFocus on Invasive Aspergillosis. Curr. Pharm. Des. 2013, 19, 3689-3712. [CrossRef] [PubMed]

40. Uicker, W.C.; Doyle, H.A.; McCracken, J.P.; Langlois, M.; Buchanan, K.L. Cytokine and chemokine expression in the central nervous system associated with protective cell-mediated immunity against Cryptococcus neoformans. Med. Mycol. 2005, 43, 27-38. [CrossRef]

41. Santiago, V.; Rezvani, K.; Sekine, T.; Stebbing, J.; Kelleher, P.; Armstrong-James, D. Human NK cells develop an exhaustion phenotype during polar degranulation at the aspergillus fumigatus hyphal synapse. Front. Immunol. 2018, 9, 2344. [CrossRef]

42. Tam, Y.K.; Maki, G.; Miyagawa, B.; Hennemann, B.; Tonn, T.; Klingemann, H.-G. Characterization of Genetically Altered, Interleukin 2-Independent Natural Killer Cell Lines Suitable for Adoptive Cellular Immunotherapy. Hum. Gene Ther. 1999, 10, 1359-1373. [CrossRef] [PubMed] 
43. Sahm, C.; Schönfeld, K.; Wels, W.S. Expression of IL-15 in NK cells results in rapid enrichment and selective cytotoxicity of gene-modified effectors that carry a tumor-specific antigen receptor. Cancer Immunol. Immunother. 2012, 61, 1451-1461. [CrossRef] [PubMed]

44. Zhang, C.; Zhang, J.; Niu, J.; Zhang, J.; Tian, Z. Interleukin-15 improves cytotoxicity of natural killer cells via up-regulating NKG2D and cytotoxic effector molecule expression as well as STAT1 and ERK1/2 phosphorylation. Cytokine 2008, 42, 128-136. [CrossRef] [PubMed] 